\title{
NEW MODELS FOR IMPROVING TEACHING AND TRAINING IN ENGINEERING AND TECHNOLOGY TRANSFER IN SOUTH AFRICA
}

\author{
L. W. Snyman* \\ Institute of Nano-Technology and Water Sustainability Research \\ e-mail: snymalw@unisa.ac.za / https://orcid.org/0000-0003-1351-5065 \\ D. Kruger* \\ Department of Mechanical and Industrial Engineering \\ e-mail: dkruger@unisa.ac.za / https://orcid.org/0000-0003-1720-0431
}

*University of South Africa, Johannesburg Campus

Johannesburg, South Africa

\section{ABSTRACT}

South Africa is in great need of improving the effectiveness of engineering and technical tuition and also enhancing technology transfer from universities to industry, the commercial sector and communities. These practices can create new job opportunities and increase the level of living standard of populations at all levels. This article highlights some models that were recently implemented at the School of Engineering of the University of South Africa in Johannesburg in order address these challenges. These included new on-line teaching methodologies with an emphasis on group work and project-based outcomes, new methodologies of work-integrated learning, the creation of an undergraduate-postgraduate dualism, a focus on innovation and product development at graduate level, and the creation of community entrepreneurship winter school programs. Measures as implemented contributed to an increase in enrolment rates 10 per cent over four years from the online teaching programmes in the diploma programme, enhanced placement of work integrated students, and eventually increased the graduation rate at graduate level by about 15 per cent over four years. Several new small companies have been created from winter school programmes.

Keywords: models, engineering, technology transfer, universities

\section{INTRODUCTION}

Traditionally, universities have been tasked with generating new knowledge and to publish internationally in this regard. Within the South African and African contexts, there are currently regular outcries in South Africa for universities to become more relevant to the country's needs; and to stimulate new job opportunities in South Africa. There is a great need to increase the effectiveness of engineering and technical tuition and also to stimulate entrepreneurship in South Africa. It would therefore be a great asset for South Africa if these goals could indeed be 
combined.

Some prime examples where academia and universities made major contributions to the infrastructure development in South Africa, is the stimulation of the steel manufacturing industries in the early nineties (Van Der Bij1 2018; Rosenthal 1966, 389-390), creation of the CSIR by Professor Meiring Naude in the 1940s (Merlot 2009); the creation and establishment of ESKOM, and exploration companies (SASOL) (Kaneko et al. 2001) the stimulation of the agricultural, forestry and wine industries in the Western Cape (University of Stellenbosch) (Elsenburg Agricultural Training Institute 2018); the development of electronics and microelectronics research and development at the University of Pretoria in the ninety seventies (University of Pretoria 2020); Prof Richard van der Ross (2018), Prof James W Gerwel and Prof Barney Pityana who all made leading contributions to the reform and development, and transformation of the education system in South Africa (Pityane 2009; Gerwel 2018).

In this article we present a few models that have been implemented at the School of Engineering at the University of South Africa's College for Science Engineering and technology in Johannesburg. We highlight the design and implementation strategies that was followed for each model, present the impact and outcomes of these implementations, and then present some summative statistics, that was observed, and to which the implemented programmes, we believe, contributed.

\section{CURRENT CHALLENGES AT ENGINEERING SCHOOLS IN SOUTH AFRICA}

The following are some of the general challenges currently relevant to South Africa, as identified by the Deans Forum of the Engineering Council in 2017 and 2018 (ECSA 2017; 2019):

Thirty to thirty-five per cent of youth under the age of 35 in South Africa are unemployed. In general, this is currently attributed to an inefficient and inadequate schooling system of the past, and also a long period of political instability due to political philosophies that was implemented, an emphasis on military defence and self-sustainability strategies of certain groups, and wrongly allocated state funds in the past. Certain sectors of the SA mining industry are currently experiencing a decline in mining activities, either due to a decline in accessing resources (gold mining) or in terms of rising international competition (steel mining and production). Competition in the manufacturing sectors in South Africa are challenging due to international trade and regulation competition and practices. The youth of South Africa demanded free education up to tertiary level. In 2015, a major campaign was launched in this regard when thousands of young people took the streets, and government and tertiary institutions had to do major adjustments afterwards. Too few small business enterprises are 
created in South Africa and too few entrepreneurial actions are stimulated in South Africa. In general, the stimulation of technology development at universities and the transfer of technology from SA universities are very low. The above are a few of the contributors to the high unemployment rate in South Africa.

The country has, furthermore, become an importer of several high technologies such as electronics, and information and communication technologies, because of a backlog in effective and sufficient training in these so-called "scarce skills" environments.

Still furthermore, most engineering schools are highly understaffed and highly underfacilitated in terms of laboratories and training equipment. Even the best equipped engineering faculties suffer from a lack of financial resources, and suffers in recruiting high-level expertise and teaching staff.

\section{SOME OPPORTUNITIES AS AVAILABLE ON THE AFRICAN CONTINENT}

South Africa generally has a good, consolidated infrastructure with some ten universities and eleven engineering schools in the country.

About four of these universities are well equipped with both undergraduate and postgraduate training facilities and are reasonably well staffed. Engineering schools generally offer two types of programmes, namely professional degrees with professional registration of engineers after study, and secondly, more vocational and technology trained engineers, offering registration for technologists and technicians after study. The qualification ratio is about five technologists or about ten technicians for each professionally trained engineer (ECSA 2019).

The Engineering Council of South Africa (ECSA) accredits all engineering programmes in South Africa. Accords exist with Washington, Sydney and the UK to recognise engineering qualifications internationally. This programme is quite active and make a great contribution towards maintaining standards in engineering training in South Africa. Engineering schools should hence support ECSA activities as far as possible.

The Department of Education has a subsidisation programme in order to stimulate research and development. Amounts are paid annually to SA universities based on research outputs (e.g. articles, peer reviewed conference proceedings, registered patents). One research agency, the National Research Foundation, subsidises and supports research and development projects based on an application and a peer review process.

Engineering as a discipline generally has a profound and immediate direct effect on maintenance of services, industrial expansions and job creation in South Africa. Engineering research and development programmes are much "nearer to market" with profound and immediate effects on economic growth and job creation and should be stimulated as a priority. 
If engineering programmes can effectively be coupled to innovation activities, a so-called double tie impact can be achieved, by, in the first instance training engineers, but simultaneously also developing products that could create manufacturing and entrepreneurship opportunities in South Africa.

The general assumption is that there are huge development opportunities in South Africa and on the African continent. We highlight only two huge opportunities, namely, (1) rich mineral resources (Dondofema, Metope and Erdogan 2017, 1-13), and (2) due to its geographical location and climate, has abundant solar energy (Bating, Musing and Brent 2017, $32-49)$.

Socialistic studies highlight that developing nations are often captured in a devasting spiral of poverty and high population growth. These studies also show that often, the best spiral out of such is the provision of high technology commodities such as electricity and modern communication. As communities develop and are exposed to higher quality of life environments, communities generally become more self-controlled and population growths stabilise (ECSA 2019).

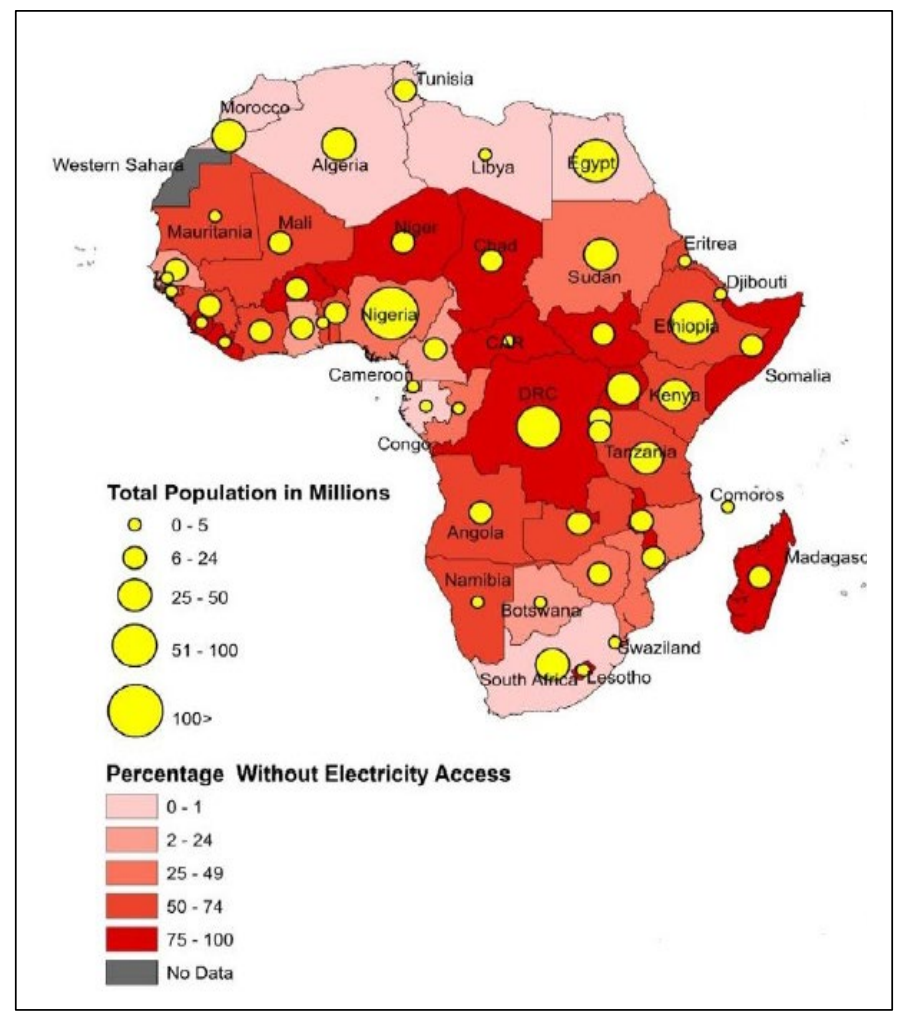

Figure 1: Overview of the energy (electricity) supply to countries in Africa.

An indication of population magnitudes is also given (after Bating et al. 2017).

Figure 2 gives an interesting synopsis of the current status quo with regard to energy supply and population demands on the African continent (Bating et al. 2017, 32-49). Morocco, 
Algeria, Libya, Egypt, Cameroon and South Africa are well-supplied areas. Countries such as Congo, Chad and Somalia are undersupplied with basic electricity access. Considering a basic need such as electricity, which is regarded as a key commodity for social and economic development, this could be identified as a key-targeted development area for South African and the African continent.

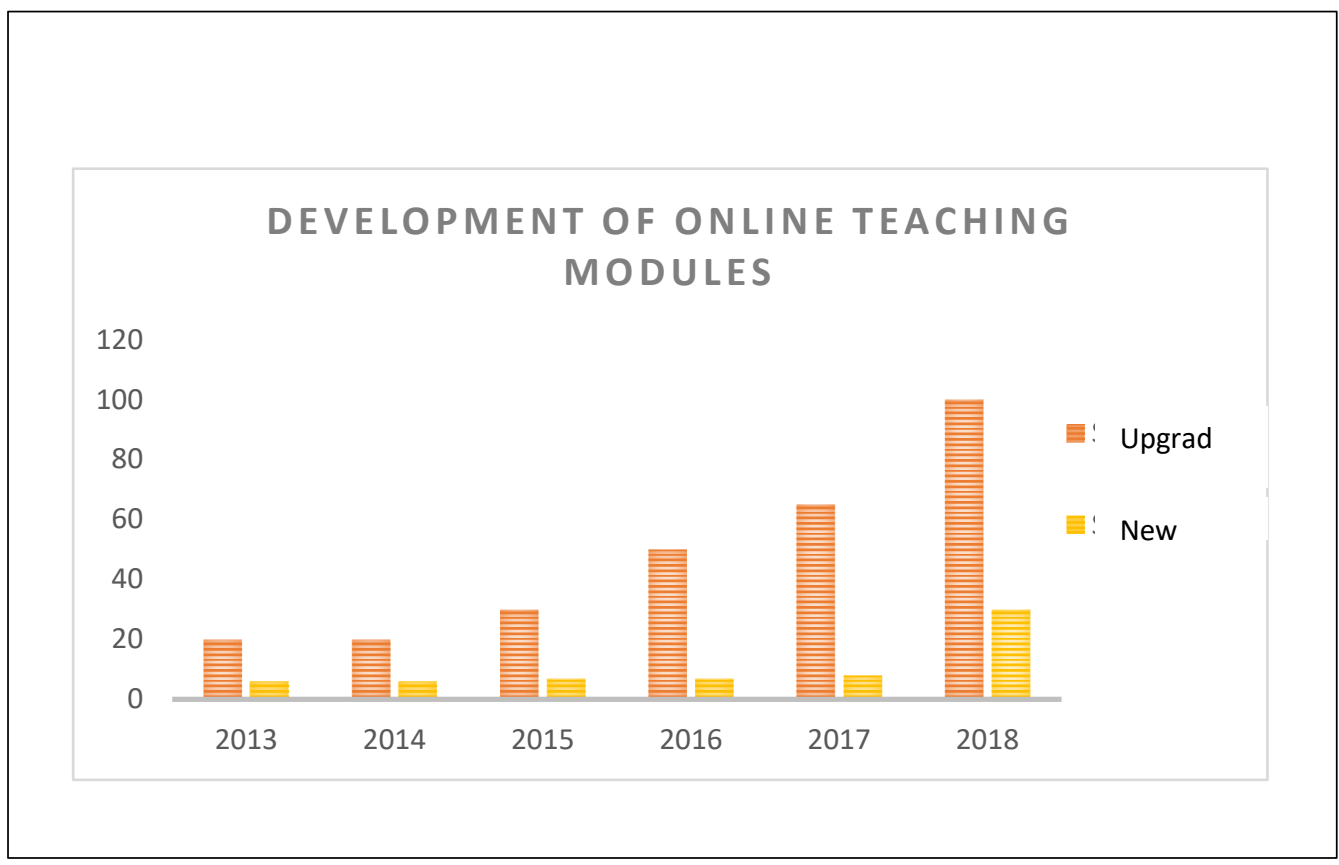

Figure 2: Investment into the development of online study models at the School of Engineering, upgrading of existing modules and development of new modules

\section{DESIGN AND IMPLEMENTATION OF SOME HIGH-IMPACT DEVELOPMENT PROGRAMMES IN ENGINEERING AT THE UNIVERSITY OF SOUTH AFRICA}

During the last few years, UNISA and the SA government have invested substantially in establishing state-of-the-art facilities and well-equipped training and research and development facilities in the Johannesburg South area, near Florida. The campus is situated in the larger metropolitan area of Soweto, near major mining industries, and the fast-growing industrial development centres of Krugersdorp, Lenasia, Lanseria, Johannesburg City Centre, and Midrand Techno parks. The College hosts three Schools, namely School of Science, School of Information Technology, and School of Engineering. The development programme has been ongoing for some ten years now. A new School of Engineering has been established on the premises. Management made a strategic choice to train students for the high vacancy and demand direction of vocational training in the National Diploma, the Baccalaureus Technologiae, and Master of Technology directions. The main mode of teaching is online teaching of engineering modules. Students in industry migrate to the main campus in 
Johannesburg for block courses in practical training. It currently hosts about 100 academics and about 60 support staff. The school has established quite strong research and development directions in fuel cells, control and systems engineering and in renewable energy technologies. During 2016 and 2019, the engineering school was evaluated by an accreditation team of the Engineering Council of South Africa and was granted full accreditation to offer programmes until 2024.

\section{Design and implementation of more effective on-line media-oriented training programmes}

One of the major strategic initiatives of the School of Engineering has been the development of a good programme qualification mix to align with government's new HEQSF requirements during 2014-2018. The School developed a blended teaching approach, that is, both hard copy and online study material were developed. Practical courses are presented on campus as an integral part of the online programmes. Students mostly study in their work envoroment on a part time basis, use state of the art online teaching software, MyUnisa, and follow a programme of work integrated learning, whereby students periodically come to the campus for short periods and receive practical training in state of the art labortaories, which have been especilaly erected and commisioned for this purpose.

As further strategic initiative, the School focussed heavily on providing good online teaching material in the engineering and technology disciplines. The School strives to provide high quality online study material, good guidance and citations to open source study material. A specific initiative was to upgrade all existing teaching and training modules. Figure 3 outlines the extent and progress made in this regard over the latter years.

A particular design approach in the new curriculum design was to include as much group work on the online My Unisa platform, and also strive to implantation of theory in a system or project design context. Study modules included a practical implantation component whereby groups of students are allocated particular components of a globular system or product design, online interaction platforms are created, and then submits written reports on each allocated assignment. These approaches hence both promoted the design and implementation aspects as well as the human interaction component, and group work aspects, which are all so important components of tuition and training in engineering.

Particularly the development of "video podcasts" proved to be a very viable method of augmenting online study material. We have, particularly, been advocating the implementation of media-assisted tuition and online tuition since the mid-nineties and did several pioneering research activities in this regard (Snyman 1993a, 224-230; 1993b; 1995, 199-203). 


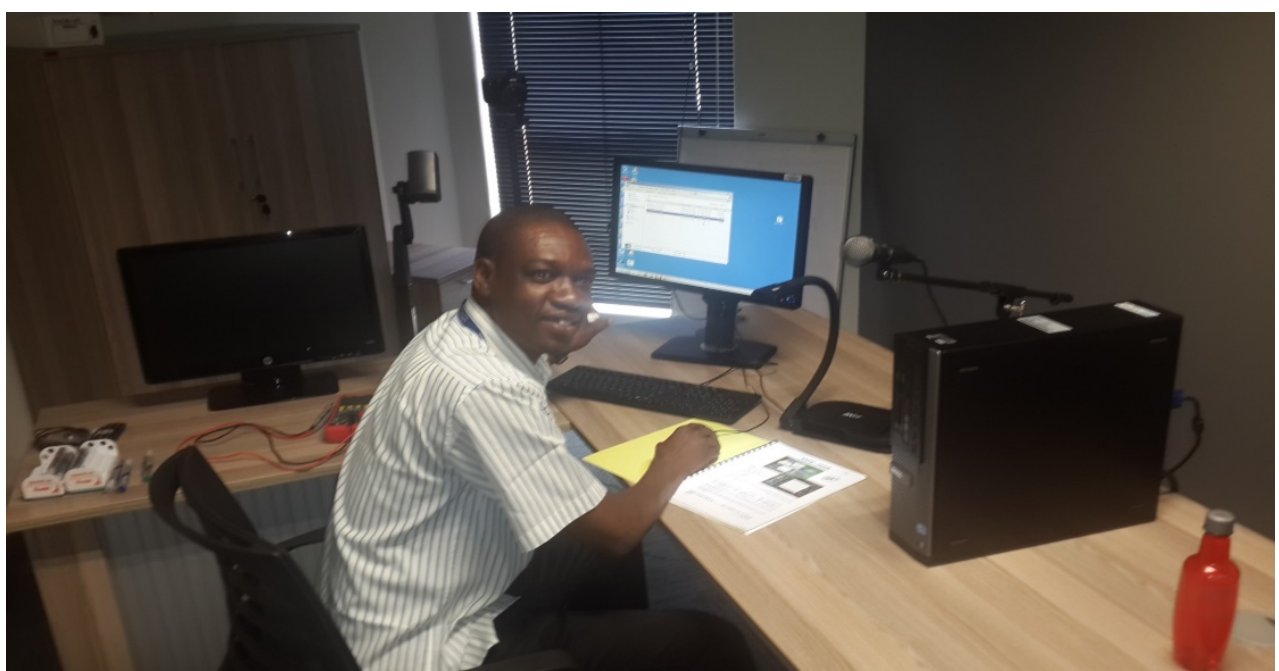

Figure 3: Interactive video studio that has been developed at the UNISA School of Engineering. The studio is near lecturer offices and can be used to make high-quality video podcast study material, which is then used in existing online tuition software on myUnisa.

To enhance and stimulate this form of teaching an "in-department video studio" was developed where lecturers can walk a short distance from their offices to a well-equipped studio with diverse video recording and processing equipment and software. Lecturers can, with little effort, make high-impact video podcasts. These podcasts and video casts can then, in a short timespan be made available on the online tuition software platform "MyUnisa" on the internet.

Currently both bandwidth and storage capacity per module page has been expanded in order to accommodate and facilitate larger quantities of these units. The video casts are also used highly effectively to personalise online teaching, to introduce lecturers, give overviews of study material, and to explain complex aspects of science, mathematics and engineering. This is delivered to students in a more personalised, visual and media-assisted format. The mathematics teaching groups are currently using this facility extensively and some results that were obtained with these new teaching methodologies have recently been published (Huntley 2017).

A further design component was to "personalise" the teaching processes as much as possible, by supplementing pod cast material with live tuition and lecturer -student interaction over the internet. This approach was particularly powerful in allowing an asynchronous teaching approach with personalised tuition included.

In some cases, synchronous sessions were also introduced whereby specific time slots were arranged on a weekly basis and students could link in in-group discussion sessions and where problematic and challenging parts of the tuition material could be addressed.

Lately, there is also a development to introduce "digitally interactive modules". These 
models are entirely software based, and a software programme are developed, that route and guide the learning process, with specifically "side route" module sections where the student did not master basic concepts and skills.

In general, the online mode of training in engineering, has become very popular, because it has enabled students who are already working in the industry to now study at reduced costs.

\section{Enhanced Work-Integrated Learning and Work-Place Learning programmes}

Work-integrated learning (WIL) is identified as a key strategy to enhance collaboration between industry and the engineering schools.

Students normally study two years for a dedicated diploma, involving completion of some twenty subjects, after which a suitable placement in industry is sought. After successful completion of their subject and theory studies, students enrol in a WIL programme for a oneyear period. The WIL programme involves a set of skills training programmes over six months involving basic metalworking, welding and brazing, and electronic circuit board design and manufacturing. This is followed by dedicated project work in the second semester, where the student must identify a suitable project in association with a suitable industry supervisor. With the inception of WIL, it was a way of imparting skills to graduating engineering students. The WIL component is mandatory for all students who enrol for the National Diploma in all engineering disciplines at institutions. It was envisaged that the programme would produce work-ready candidates.

As a specific design strategy, the engineering school at UNISA created a special "Resource and Support Office" for supporting students with WIL practices. The main functions of this office were to compile CVs of students, to compile an extensive database of companies that offer placements to students, and to manage and facilitate a web-based processing system to assist and enhance WIL placements in the industrial and commercial sector in South Africa. A specific derivative of the WIL programme from 2014-2018 was, hence, to develop a system of work-place learning (WPL). This was implanted through developing two compulsory modules in a vernacular, known as P1 and P2. The tag of work readiness of graduates was the key factor in this instance before placements was made.

Because of various external factors, the modules have a severe effect on the number of students graduating every year.

A major issue regarding the placement of WPL was the disconnect that existed between the HEIs and industry. The pure academic learning in the engineering disciplines is undertaken by the HEIs. Due to numerous practical issues, the practical part of the syllabi is outsourced to industry. In many instances, a severe misalignment exists between the requirements of the 
institution and the industry participant. One of the contributing factors to the misalignment was the fact that WPL is interdisciplinary. Hence, not all industry participants had sufficient trained engineers to mentor WPL students through the process.

The WPL entails the application of the knowledge gained by the student to real-time problems in an industry. A major disadvantage of none placement of students is that students cannot graduate due to the non-completion of their WPL modules.

\section{Creation of a postgraduate undergraduate dualism in operation}

A dedicated system of "integrated UG-PG" programmes was designed at UNISA School of Engineering from 2014 to 2018.

To this end, a set of dedicated PG laboratories were developed, each in a specific focused discipline, with a high market application, and with the aim of developing more advanced systems and subsystems that are relevant for the SA industry and the African continent.

Foci were research and development in telecommunication, radio frequency system and subsystem design, and renewable energies.

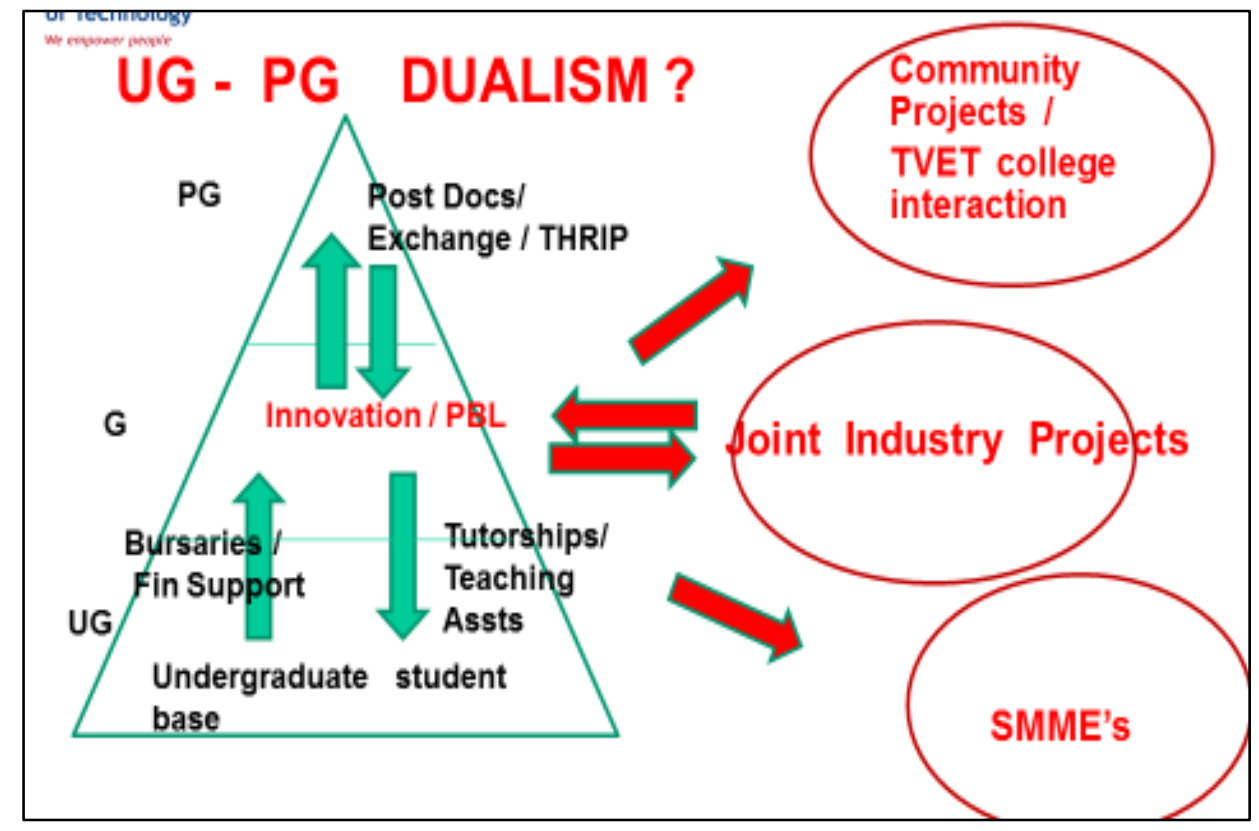

Figure 4: Schematic illustration showing the integrated Undergraduate - Postgraduate symbioses program that have been developed at the School of Engineering 2012 to 2017. A focus is placed on stimulated project-based learning at a Baccalaureus level with a focus of developing innovative products which then supports both the undergraduate and postgraduate training programmes.

A very special management system was implemented to sustain the postgraduate laboratories. A system was developed where UG programmes were used to cross subsidise PG programmes. PG students were offered research and teaching assistantships to support their postgraduate studies. Students were recruited to assist professors and lecturers with practical and tutorial 
presentation and assessment practice, while simultaneously students were paid small salaries for these services as provided. These funds could then enable PG students to support their postgraduate studies and doctorate level at the School.

Figure 4 presents an idealistic model that were designed for this purpose. Sufficient management opportunities were especially created at the graduate level for the creation of entrepreneurial activities and the transfer of technologies to both the private, commercial and industrial sector.

\section{Introducing innovation product-oriented programmes at graduate level which can stimulate entrepreneurship}

During the period 2010 to 2018, a specific new programme of directed entrepreneurship was designed and developed at UNISA School of Engineering. This followed a similar model that was designed at the Tshwane University of technology (TUT) (while the main author was employed there).

A small, dedicated laboratory was set aside in the Department of Electrical Engineering, in order to accommodate "work-integrated student training" on the campus itself. A special laboratory manager was appointed and a team of dedicated lecturers was allocated to the laboratory. The lecturers then advertised available projects in the passages on a semester basis, and students could apply for the projects. A similar as for the WIL industry training programmes were implemented, except that the project was entrepreneurship and innovation oriented. Academics and students were asked to observe closely everyday life in South Africa, follow market and economic development trends in South Africa and in Africa, and then to identify a "marketable product" i.e. some product that could "sell" in the free market. The project entailed six phases: (1) appropriate intellectual property protection of the idea by means of patenting or non-disclosure (NDA) agreements, (2) design and business plan, (3) simulation and other preliminary verification studies, (4) prototype construction, (5) testing of performance characteristics of the prototype and (6) documentation and presentation of results.

\section{High impact community outreach programmes}

During 2017, the management of the School of Engineering at UNISA, in Johannesburg South, designed a so-called high impact community outreach project and a School of Engineering Winter School as a test and pilot project (UNISA 2017).

The aims and procedures around the Winter School were implemented by inviting unemployed youth "from the street" and underdeveloped communities and expose them to basic technical and manufacturing skills in the engineering and innovative product sectors, 
particularly in renewable energies, for which a market exists in South Africa and Africa.

Academia made presentations on their ideas of innovative products and presented basic viable business plans.

In subsequent weeks, students were divided into groups of their choice, and exposed to the design aspects surrounding each product. In subsequent weeks students learned the basic skills around the manufacturing around each product, including mechanical design, electronic subsystem design and software development, and, construction and testing of a first prototype of the product.

A Winter School of this nature equipped current undergraduate and postgraduate students with specialized skills and prepared them better for the existing industrial market in South Africa, but also equipped people from underdeveloped communities that are currently unemployed with basic technical and manufacturing skills. They could then be enabled to start their own new business enterprises in South Africa.

Aspirant enrollers for the course were encouraged to apply for support funding for attendance of the programme from their local community development offices in the respective regions in South Africa. School attendees could interact with local representatives from the Technology Innovation Agency (TIA) and the Department of Trade and Industry (DTI), who could assist scholars with compiling business plans for aspirant SMME's and application for seed funding.

\section{OUTCOMES AS EMANTED FROM THE RESPECTIVE PROGRAMMES}

\section{Introduction of dedicated online study material and introduction of personalised tuition through podcasts and live interaction sessions and increased Work Place Placements}

Figure 5 shows a reasonable increase in the enrolments at undergraduate level of approximately 10 per cent per annum over five years. This is particularly attributed to the relevance of the qualifications as offered by UNISA in terms of vocational diploma programmes offered to students at affordable costs. Particularly noticeable is the high growth of students that have registered for graduate B.Tech degrees. This high growth is particularly attributed to well managed and registration for B.Tech project work in the workplace, with a system of a localised supervisor which is appointed in industry and being contracted to attend to the training of the student. 


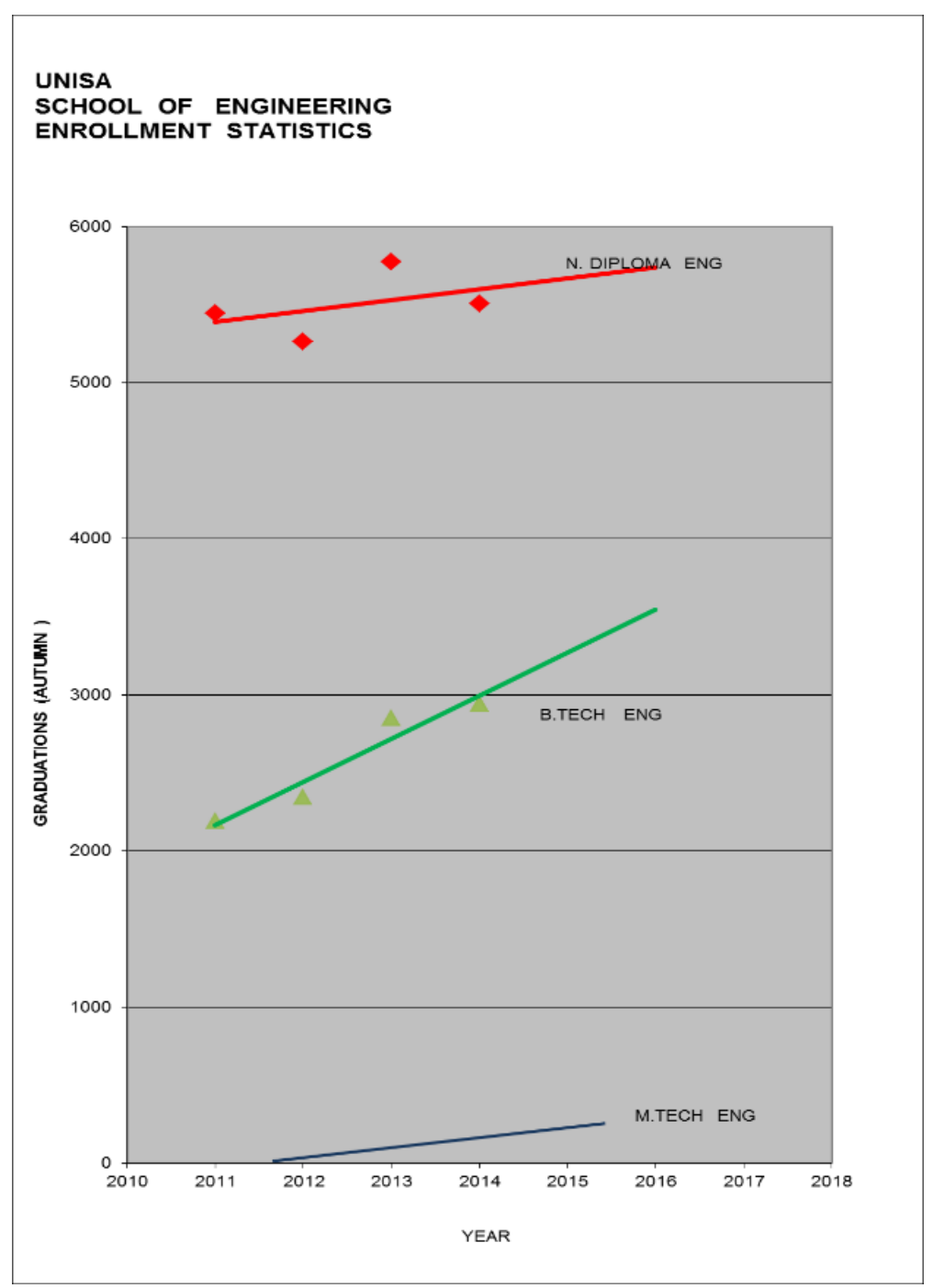

Figure 5: Enrolment rates as recorded at the School of engineering, UNISA for Diploma, Baccalaureus and master's students in the period, 2010 to 2016.

Also, particularly noticeable is the steady growth of postgraduate enrolments as demonstrated in Figure 6. This growth was particularly stimulated by the good exposure of academia to students in the industry, the availability and appointment of a number high ranking specialists and research professors, and a very effective online research and innovation project advertisement on the Web. This system also enabled the direct application for postgraduate research projects either online or by contacting the supervisors directly.

Also, particularly noticeable in the statistics, is the sharp growth of graduations at both diploma and B.Tech level that was experienced over the last two years. These trends were attributed to the increase in efficiency of the WIL management system that was implemented over the last two years by assisting students with placement on a fully interactive online Web based system, as well as by absorbing a number of a students in research laboratories at the 
UNISA campus in Florida in order to complete their WIL and B.Tech projects in the UNISA laboratories. We found that many students could not get placement in industry due to the high unemployment rate in South Africa.

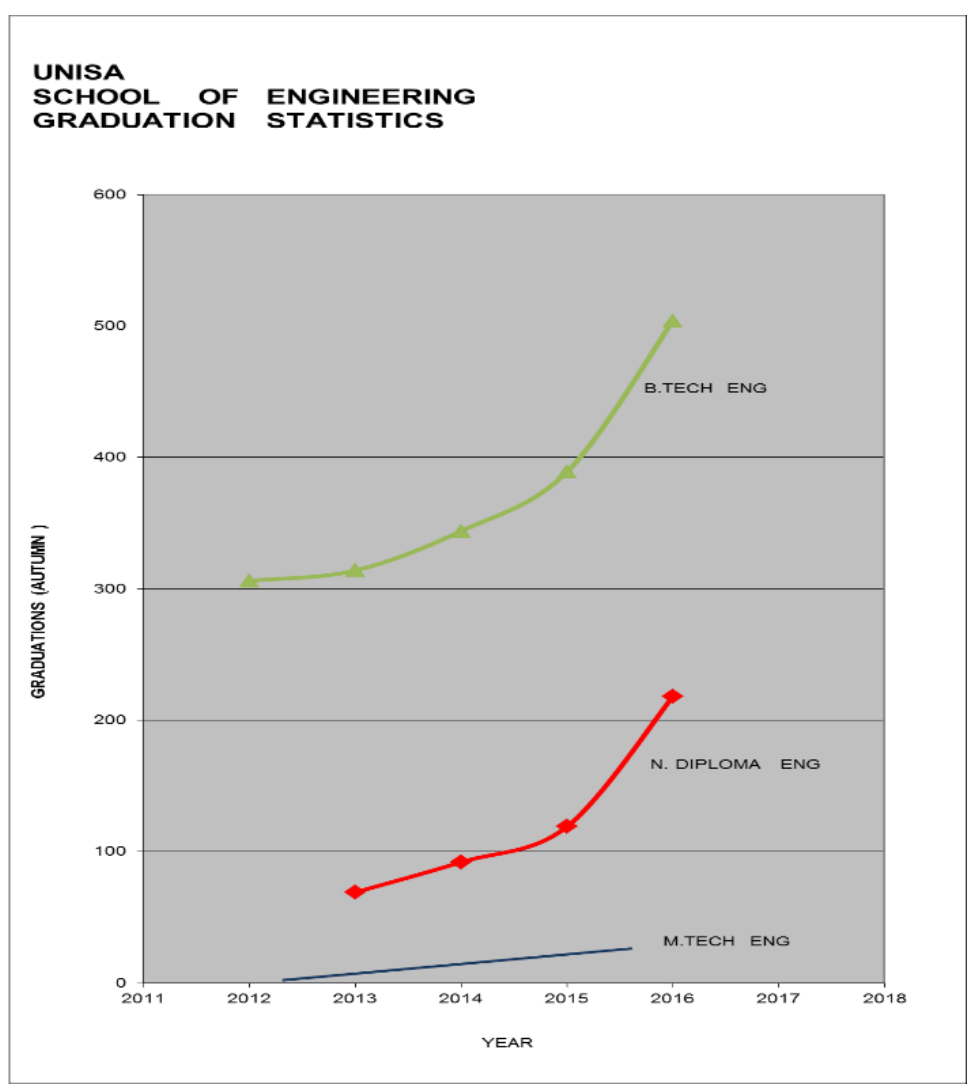

Figure 6: Achieved graduation rates as recorded at the School of Engineering, UNISA for Diploma, Baccalaureus and master's students in the period, 2010 to 2016.

It is concluded that the specific design of the School of Engineering's online study modules with an emphasis on quality and effectiveness in tuition, the particular increase in modules as developed over a number of years, as were outlined in Figure 2, together with the introduction of personalised teaching in a predominantly previous online text based environment, was major contributors towards the increased in enrolment rates and pass rates as were observed.

\section{Increased WPL Placements}

It is believed that these actions as outlined in the section on enhanced WIL and WPL programmes enhanced the throughput of students and enabled students to complete their studies over a shorter extent of time. A snapshot of WPL enrolment at UNISA was taken for students enrolled for the modules at the end of January 2017 is shown in Figure 7.

Considering the trends in the figures, one finds that, in overall, there were 187 enrolments 
for WPL for 2017. Of these, 112 were unable to find placement (adding no placement and uncertain). It represents a 59,89 per cent unplaced rate. This means that almost 60 per cent of total enrolled students cannot graduate because of incomplete WPL modules.

There are very few arguments that can dispute the importance of gaining knowledge and skills in a working environment, backed with appropriate theoretical tuition. This manner of delivering such remains open for debate, and probably needs much further research and development. However, the enrolment and placement statistics as shown in Figure 7 clearly shows that UNISA succeeded in a good eventual placement of students in the industrial and commercial sectors in South Africa in 2017. The statistics at UNISA furthermore show a clear growth of about 5 per cent per annum between 2014 and 2018.

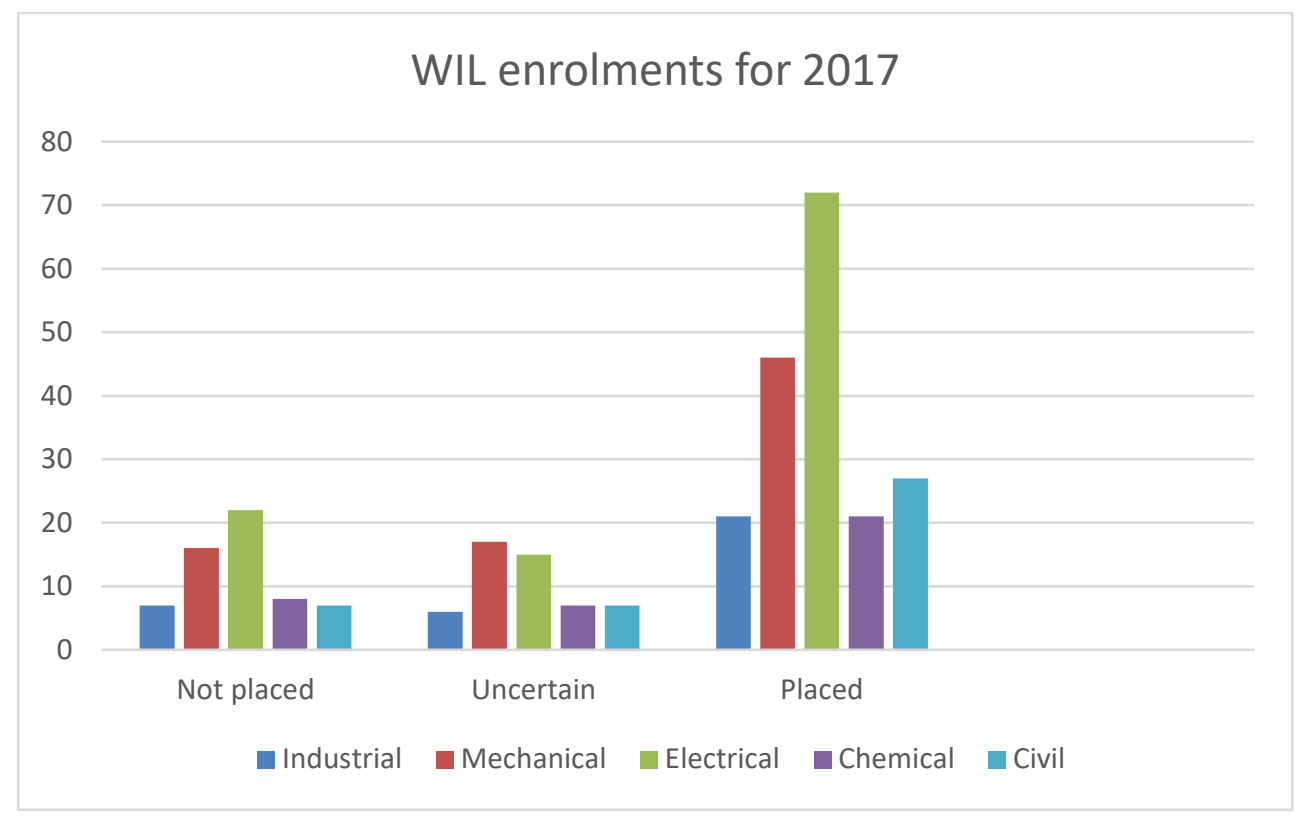

Figure 7: WIL placement statistics at UNISA for all engineering disciplines

\section{Creation of a postgraduate undergraduate dualism in operation}

This system worked extremely well during the period 2010 to 2018 at both the TUT and the UNISA School of Engineering where it was introduced.

Especially foreign students from Africa were deployed most effectively in this model. These students normally had a good background in mathematics and basic physics, and were very keen to learn and apply more practical technologies and initiatives.

Some African students eventually trained according to certain schemes internationally, and proceeded with advanced point graduate studies at technical universities in France, and eventually became engineers in high-ranking French entrepreneurial companies. Other students 
were very effectively absorbed in the SA industrial environment.

Challenges in this period were that the SA labour law regulations that did not allow foreigners to take up permanent jobs or receive a salary for longer than two years in SA, hence the securing of external funding through the NRF and THRIP programmes were mostly utilised in these programmes.

\section{Dedicated innovative product development at graduate level.}
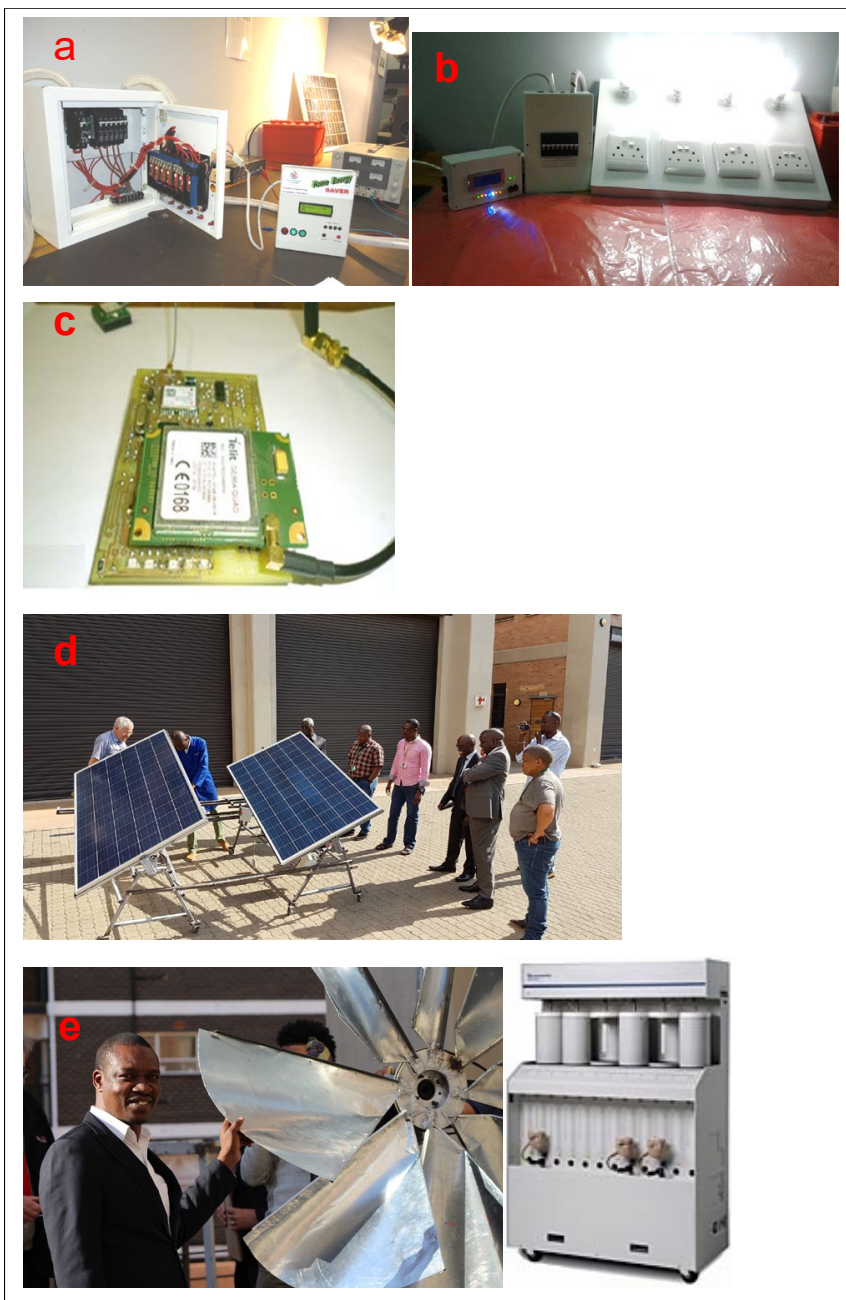

Figure 8: Collage of entrepreneurial product prototypes that have been developed at the Engineering and the School of Engineering at the TUT and UNISA from 2010 to 2018. (a) and (b) Cell phone-controlled household energy manager. (c) Micro-card tracker. (d) Tiltable panel and mobile photovoltaic energy supply unit. (e) Low-cost wind turbine electricity generator.

Many products were developed with an application in the man-to-machine interfacing, where radio frequency technology, microprocessor systems and advanced software were used to link with cell phones, and control and convey information through cellular networks. With such systems many smart energy control systems were developed, where cell phones could be used to control and manage households' renewable energy systems and an office environment system 
with a focus on user friendliness and automation (Snyman et al. 2001; Snyman and Ehrhardt 2002; Van Eldik and Snyman 2001; Snyman and Ntuli-Mpapama 2018; Snyman 2020).

Figure 8 shows a collage of entrepreneurial projects that were developed at the TUT as from 2010 and at UNISA from 2014 to 2018. In the first case, projects were defined around radio planning for cellular networks, advanced antenna design and management of cellular applications, as well as subsystems development for the optical fibre industry, at a system, subsystem and microelectronic level. In the latter application, projects were particularly designed around microprocessor control system and subsystem design for the control and automation related to photovoltaic collection and energy distribution systems.

All the products were intellectually and copyright protected by UNISA. The licencing and IP management to manufacture and produce these products will not be extravagant, but the intention is to ensure a small capital back flow to the university, inventors and contributors as compensation for various investments made into the program and product developments.

\section{Winter Schools and high impact community outreach programmes}

The Winter Schools that were presented at UNISA School of Engineering in 2015 and 2016 served as a good example where innovative technology can make a high social and economic impact in societies and improve the living standard of individuals. The technologies as were developed had a specifically African flavour and application. The product could be cost effectively manufactured using local manpower and local materials. The products all had a selected small high technology content. The products may in future be exported to other countries and compete internationally on the free market. The current weak SA Rand International Currency ratios favours local manufacturing and cost-effective export operations.

In overall, the Winter School presented a win-win situation for many parties. Academia saw their ideas and that were shelfed as reports on shelves, come to life. For the first time, postgraduate students gained enormously from the exercise as they had many hands to assist them with their designs and build prototypes in a very short period of time (after they could pursue with measurement results). TVET college students were exposed to new ideas and business plans, and unemployed youth could utilize the opportunity to become involved on projects on a self-employed basis. Indeed, great partnerships could be established for the longer term in South Africa.

In the process, hundreds of new job opportunities were created in both South Africa and Africa. Particularly, Figure 8(d) presents a "Low Cost and Mobile Photo-voltaic power generation system" that could be deployed in rural Africa to generate power to small rural communities on an as needed basis. The system used adaptive technology involving smart 
cleaning of the surface of the panel, tilting of the panels to the sun to increase absorption of solar energy, as well as advanced impedance matching technology to ensure optimum power transfer. The first prototype had a simple lever such that the panel can be tilt-locked in various positions, manually by a person, such that the panel could "follow the sun" as it passes over. Tilt and inclination angles were optimised for the DRC Congo area. Subsequent tests revealed that the system had up to 66 per cent increase in power output as compared with other "conventional stationary, imported" systems.

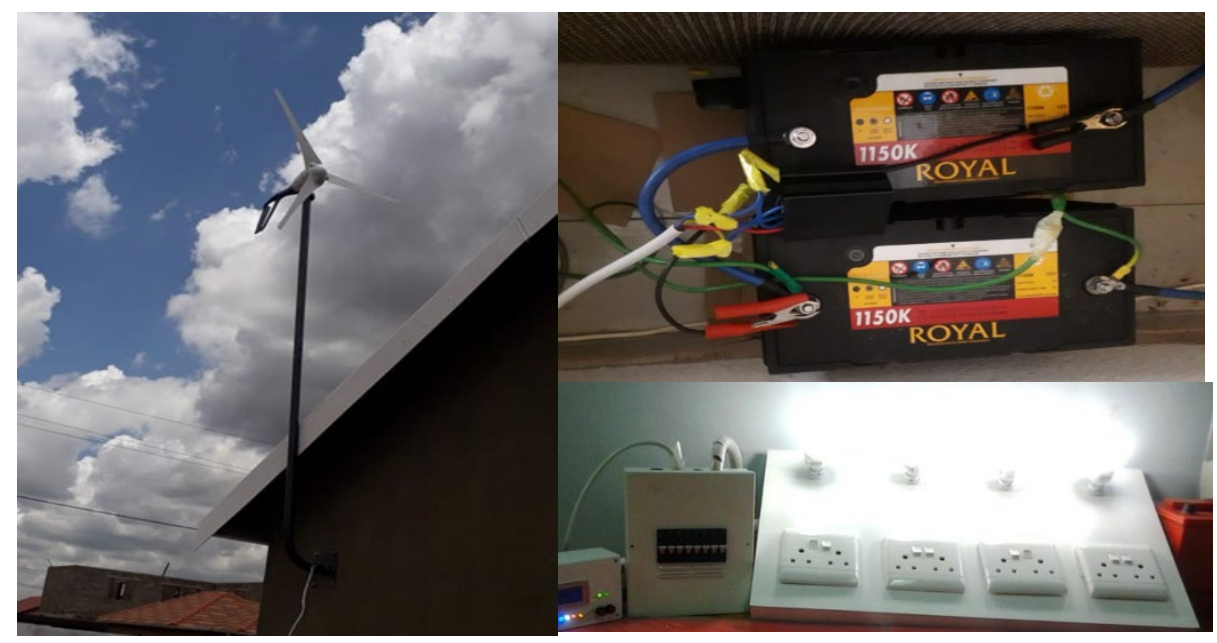

Figure 9. Recently constructed wind turbine as developed by M.Tech student Tshepo Sithole in Soweto. The system could generate enough electrical power to supply a small household of electricity for one day.

It also delivered peak power for longer periods during the day. In total the adaptive technologies reduced the $\mathrm{kWhrs}$ per operational time over 10 years by almost a half (R2.20 per $\mathrm{kWhr})$. The system was the first of its kind in a rural Congo area. For the first time, it supplied a complete household in the community with electricity power. The community and household celebrated for one full weekend after installation and demonstrations. It was accepted with great enthusiasm and joy by the rest of rural community when completed. Currently, a further prototype has already been developed by the same PG students, including an automated motorising and sensor-based control system for automating the tilting operation. A certificate of competency was issued to each person.

Also, Figure 9 presents a "Low-cost wind generator system as deployed in Soweto" as were implemented in association with a postgraduate masters student. There are strong evening and night drafts in the area, giving enough energy to supply a complete small household of electricity for one day. The energy as collected are stored in two big storage batteries and used during day time to run household appliances. The cost outlay of the system is about R8000. Payback tariffs can be arranged over a specific time after which energy collection is free. The 
lifetime of the system is about twenty years with minimum of maintenance. Some components were imported from China. The average cost per kWhr over 10 years is about 0.80 ZAR.

\section{OVERALL CONCLUSIONS AND RECOMMENDATIONS}

The following major conclusions are derived from the presented tuition design models and outcomes of the case studies as presented:

1. The specific design and implemented strategies with regard to increase in increasing the effectiveness of online modules by means of "for purpose" design as required by the engineering profession, by promoting personalised tuition through video and podcasts, promoting group work, promoting project-based tuition, and promoting the development of communication skills, indeed contributed towards increasing the enrolment rate of students as well as contributed towards higher graduation rates.

2. The design models with regard to Work integrated Learning practices by introducing a specific management system in order to manage recruitment, monitoring student involvement through surveys, and increasing the placements of students; all had a major impact on increasing the effectiveness of Work Integrated Learning Programmes at the University of South Africa. These practices also remarkably increased the collaboration between the university and the private and commercial sectors in South Africa.

3. The particular design model of creating an undergraduate postgraduate symbioses and mutually managing both undergraduate and postgraduate programmes together and mutually supporting each programme through enhanced tutor support and financially supporting postgraduate simultaneously, had a major impact of increasing the effectiveness of each programme.

4. It was observed that the introduction of innovation-oriented projects at a graduate level and also in winter schools directed to unemployed youth had marked outputs in terms of more directed training of students that could stimulate entrepreneurship and job creation in South Africa.

5. It is believed that all of the above models and strategies could have marked influences on the effectiveness of engineering tuition in South Africa in future, if taken note of by other institutions, and may be also implanted in the same of modified forms. The presented models and practices should also be seen as first iteration implementations and it could indeed provide opportunities for further research practices and development opportunities. 


\section{ACKNOWLEDGEMENTS}

The following persons are thanked for providing statics and supporting material for this article: Previous Director and founder of the School of Engineering at UNISA, Prof Andre Geertsema for providing vital information of strategic initiatives at inception of the School and subsequent statistics about enrolments and success rates; Mrs Dorian Ionesco, current coordinator of the new programme qualification mix at UNISA; Mrs Renita Meyer for proving statistics about the study guide development programme through the Department of University Teaching and Learning Development (DUTLD) at CSET, UNISA; and Management, collegial staff, $\mathrm{Mr}$ Johan De Koker for assisting with the Winter School of 2017; and all postgraduate students and colleagues that have enthusiastically co-incepted, co-worked and co-managed the various initiatives as presented in this article.

\section{REFERENCES}

Bating, B., J. K. Musing and A. C. Brent. 2017. Leapfrogging to renewable energy: The opportunity for unmet electricity markets. South African Journal of Industrial Engineering 28(4): 1-13, 32-49.

CSIR. 2013. The Innovation Hub to strengthen innovation in Gauteng. https://www.csir.co.za/csir-andinnovation-hub-strengthen-innovation-gauteng. Wikipedia. (Accessed 18 February 2018).

Dondofema, R. A., S. Metope, and G. Erdogan. 2017. South African iron and steel industrial evolution: An industrial engineering perspective. South African Journal of Industrial Engineering 28(4): 113.

ECSA see Engineering Council of South Africa.

Elsenburg Agricultural Training Institute. 2018. Home page. Wikipedia. (Accessed 14 February 2018).

Engineering Council of South Africa. 2019. Official Web Site. https://www.ecsa.co.za/. Also Wikipedia. (Accessed 14 February 2020).

Engineering Council of South Africa. 2017. Minutes of the Deans Forum of Engineering Council of South Africa.

Gerwel, J. 2018. South African. Wikipedia. http://www.sahistory.org.za/people/professor-gert-jakesjohannes-gerwel (Accessed 14 February 2018).

Huntley, B. 2017. Analyses of performance of students studying mathematics as function of instructional conveyance. Open Distance Learning Conference of CSET, September 2017.

Kaneko, T., F. Derbyshire, E. Makino, D. Gray and M. Tamura. 2001. Coal liquefaction. Ullmann's Encyclopedia of Industrial Chemistry. Weinheim: Wiley-VCH. doi:10.1002/14356007.a07_197. ISBN 9783527306732.

Merlot, R. 2009. Southern African Association for the Advancement of Science. Pretoria.

Pityana, Barney Nyameko. 2009. South African History. http://www.sahistory.org.za/people/professorbarney-nyameko-pityana. Merlot Rudolf Brochure. Southern African Association for the Advancement of Science. Pretoria: S2A3.

Rosenthal, E. 1966. Southern African Dictionary of National Biography, 389-390. Frederick Warne and Co. Ltd.

Snyman, L. W. 1993a. The design of distance training programs for South Africa with an emphasis on low cost and didactical efficiency. Proceedings of the 1993 IEEE South African symposium on communications and signal process (COMSIG) Conference, 224-230. Johannesburg, South Africa. 
Snyman, L.W. 1993b. Stimulation of the sciences in South Africa through instructional television. Proceedings of the 38th South African Institute of Physics Conference. Stellenbosch, South Africa.

Snyman, L. W. 1995. Low cost and localised distance training systems in South Africa, using television as medium. South African Journal of Higher Education 9(1): 199-203.

Snyman, L. W. and J. Ehrhardt. 2002. Training-based implementation of DECT and GSM networks in underdeveloped areas in South Africa. Quantum: Journal for the Electronics Professional: 27-29.

Snyman, L. W., A. Hattingh, S. Goes and P. van Elda. 2001. Introducing entrepreneurial training programmes at Technikon Pretoria. School of Electrical Engineering, French South African Technical Institute in Electronics, Technology Station in Electronics and the Department of Information and Strategic Planning, Technikon Pretoria. Proceedings of the Technology Forum Conference, 37-57. CSIR Conference Centre.

Snyman, L. W and T. Ntuli-Mpapama. 2018. Patent power - UNISA is serious about solar energy. Research Insights, November 2018.

Snyman, L. W. 2020. Most prolific inventor of UNISA, 2015-2020. Research Bulletin, UNISA, April 2020.

UNISA see University of South Africa.

UNISA. 2017. Winter school for Community Outreach and stimulation of Entrepreneurship in SA, 124. College of Science Engineering and Technology.

University of Pretoria. 2020. Wikipedia. (Accessed 31 August 2020).

University of South Africa. 2020. Official Site. http://www.unisa.ac.za/. Wikipedia. (Accessed 14 February 2020).

Van de Ross, R. 2018. Rector of University of Western Cape. http://www.sahistory.org.za/datedevent/prof-richard-ernest-van-der-ross-rector-university-western-cape-born-plumstead-capetown.

Van der Bijl, H. 2018. Wikipedia. (Accessed 14 February 2018).

Van Eldik, P. and L. W. Snyman. 2001. "The University of Technology - Its role in innovation and incubation." Department of Information and Strategic Planning, French South African Technical Institute in Technology. Proceedings of the Edutech Conference. Eskom Conference Centre, South Africa, 